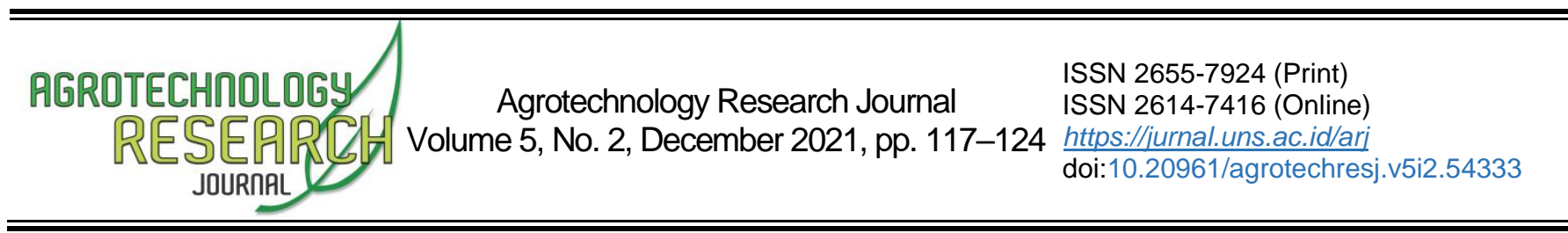

\title{
Response of Basil (Ocimum basilicum) Growth and Yield to Planting Densities and Row Arrangements in Tomato-Basil Intercropping System
}

\author{
Midekesa Chala Mamo ${ }^{1 *}$ \\ ${ }^{1}$ Ethiopian Institute of Agricultural Research, Ambo Agricultural Research Center, P.O.Box, 37, Ambo, Ethiopia
}

Received 12 August 2021; Accepted 08 November 2021; Published 31 December 2021

\begin{abstract}
Wondo Genet area, which is located in the Sidama zone of south Ethiopia, is characterized by a rapidly increasing human population and scarcity of arable land per household. There is a need for developing an efficient cropping system to use the limited land efficiently and to enhance food security. An experiment was, therefore, was conducted at Wondo Genet Agricultural Research Center under irrigated during the 2018 cropping season to examine the growth and yield of sweet basil under different planting densities and row arrangements in tomato-sweet basil Intercropping System. The experiment was conducted with two basil row arrangements (one tomato row alternating with one basil row (1T:1B) or with two basil rows (1T:2B)) and four basil population densities (66666, 50000, 33333 and 16666 plants.ha-1) factorial arrangement in RCBD with three replications each consisting of ten treatments. Results of the study indicated that the row arrangement by planting density interaction significantly influenced the yield of basil with the maximum dry herbal (341.49 kg.ha-1) and essential oil $\left(22.86 \mathrm{~kg}^{-1} \mathrm{ha}^{-1}\right)$ yields were recorded at $100 \%$ basil population density with a 1T:2B row arrangements. The cropping system significantly influenced the essential oil content and essential oil yield of basil. The highest essential oil content $(1.26 \%)$ and essential oil yield $\left(21.83 \mathrm{~kg}^{-\mathrm{ha}^{-1}}\right)$ of basil were obtained at sole planting compared to that of intercropping $(0.96 \%)$ and $\left(15.36 \mathrm{~kg}^{\left.-\mathrm{ha}^{-1}\right)}\right.$ with tomato showing $23.81 \%$ and $29.64 \%$ reduction, respectively. Therefore, intercropping $100 \%$ basil population in tomato by 1T:2B row arrangements could be recommended for Wondo genet and similar agroecology area, based on its better compatibility and productivity.
\end{abstract}

Keywords: cropping system; essential oil; intercropped

Cite this as (CSE Style): Mamo CM. 2021. Response of basil (Ocimum basilicum) growth and yield to planting densities and row arrangements in tomato-basil intercropping system. Agrotechnology Res J. 5(2):117-124. https://dx.doi.org/10.20961/agrotechresj.v5i2.54333.

\section{INTRODUCTION}

Globally, cultivable land has decreased due to rapid population growth and industrialization. Particularly in Asia and Africa where producers have small plots, agricultural areas are under pressure to produce greater quantities of food, feed, and biofuel on limited land resources (Ebert 2014). While global demand for food increases, agricultural expansion faces more strong environmental preservation demands and sustainability laws aimed at the prevention of deforestation (Crusciol et al. 2014). Industrialization and globalization in coupled with climate changes endanger agriculture and the future of humanity and the environment. Modern industrialized agriculture based on monoculture can lead to unsustainable environments such as building up disease pressure and reducing particular nutrients in the soil (Salaheen and Biswas 2019). Monoculture increase disease pressure and decline soil fertility resulted in

${ }^{*}$ Corresponding Author:

E-Mail': chalamidekesa@gmail.com increased crop yields with huge costs of production for synthetic fertilizers and pesticides (Yildirim and EkIncl 2017).

Intercropping is one of the most effective methods in agricultural production with a long history and widespread application in the tropics, as it reduces losses caused by pests, diseases, and weeds, and also guarantees better yields. Some short-duration crops, especially spices condiments and medicinal plants, if planted as an intercrop in or around the main crop, may reduce pest incidence, due to their pungent aromatic odor in the field (Gebru 2015). Medicinal and aromatic plants (MAPs) play a significant role in the uplifting rural economy and thus, their demand is increasing all over the world (Rao 2002; Mishra et al. 2020). However, they are less cultivated by farmers, because their cultivation as a mono-crop involves certain risk and their economic returns are uncertain. One of the means to address the issue would be to promote the cultivation of medicinal plants as inter-crop with local food crops. Numerous studies reported that such an inter-cropping system would increase the marginal incomes, especially for the small farmers, apart from meeting the market demand 
and helping in the conservation of the wild types (Nigussie et al. 2017; Machiani et al. 2019).

Basil and tomato are believed to be companion plants with similar light and water requirements and in the same cases, tomatoes taste better when they neighbor basil (Pereira et al. 2015; Gomes et al. 2021; Yaldiz and Camlica 2021). According to Carvalho et al. (2017), higher tomato yields have been observed under intercropping with aromatic plants as compared to tomato alone, and thus, intercropping is a more profitable system. It has also been observed that basil can attract some bacteria and Arbuscular mycorrhizal fungi (AMF) and helps prevent diseases in tomatoes and increases the biomass yield of tomatoes (Hage-Ahmed et al. 2013).

Enhancing the productivity of tomato and basil intercrops requires improving the interspecies complementary action or reducing the competition effects. Planting density is one of the most important agronomic management decisions to be considered when deciding to practice intercropping. Sattler and Bartelheimer (2018) noted that poor management of planting density could be detrimental to intercropping. Plant densities that are too low may limit the potential yield while plant densities that are too high may lead to increased stress on the plants, and increased interplant competition for light, water, and nutrients (Adeniyi and Omotunde 2001) which also decrease the yield. The other important management aspect is row arrangement which can improve radiation interception through more complete ground cover and determine whether an intercropping system would be advantageous or not concerning yield gains (Nthabiseng et al. 2015).

Wondo Genet area, which is located in the Sidama zone of southern Ethiopia, is characterized by a rapidly increasing human population and is suitable for vegetable production but with a scarcity of arable land per household. There is a need for developing an efficient cropping system to use the limited land efficiently and to enhance food security. Since the shortage of arable land is a constraint; optimizing intercropping performance can assist the effective use of space and nutrients (Lulie 2017). Smallholder farmers in the Wondo Genet area grow tomatoes both under rainfed and irrigated conditions. Moreover, growers have been challenged by inconsistent production and low yields. Inter-cropping vegetables on small land of the home garden is traditionally a common practice in the Wondo Genet area. However, the arrangement of crops is at random with an improper planting density of component crops, which results in poor crop yields. Even though it is possible to increase tomato production by intercropping with basil, yet no research has been done to determine optimum population density and row arrangement of basil for tomato-basil intercropping in the area. Considering the above-indicated gaps this work was initiated with the objectives to determine the optimum planting density and row arrangements of basil for intercropping with tomato and to examine growth and yield of sweet basil under different planting density and row arrangements under tomato-basil inter-cropping system under irrigation.

\section{MATERIALS AND METHOD \\ Description of experimental site}

The experiment was conducted in the field at Wondo Genet Agricultural Research Center (WGARC), Southern Ethiopia, under irrigated conditions in the 2018 dry-off season. The research center is located $264 \mathrm{~km}$ south of Addis Ababa and $14 \mathrm{~km}$ southeast of Shashemene town. It is located in Sidama Zone, Southern Nations Nationalities and People's Region (SNNPR), of Ethiopia at latitude 7019 'N and longitude 38038' $E$ an altitude of $1780 \mathrm{~m}$ above sea level (ASL). The site has mean annual total rainfall of $1121.8 \mathrm{~mm}$ with mean maximum and minimum temperatures of $260 \mathrm{C}$ and $120 \mathrm{C}$, respectively. The soil of the study area has clay loam texture (sand $=38$, clay $=37$, and silt $=25$ ) with $\mathrm{pH}$ values of 6.92, (neutral in reaction) and is low in organic matter content $(3.46 \%)$, medium in total $\mathrm{N}$ $(0.154 \%)$, low in available $P\left(2.54 \mathrm{mg} \mathrm{kg}^{-1}\right)$, and high in CEC (43.7 $\left.\mathrm{cmol} \mathrm{kg}^{-1}\right)$. Wondo Genet has a bimodal rainfall distribution with two rainy seasons. Short rains occur from March to May and the long rains from July to October.

\section{Experimental materials, design, and treatments}

Seeds of a tomato variety Melka Shola obtained from Melkassa Agricultural Research Center (MARC) and a promising genotype (B04) of basil from Wondo Genet Agricultural Research Center (WGARC) were used for the experiment. Tomato variety Melka Shola is a determinate type and can be used for dual purposes and well adapted to Wondo Genet conditions. Melka Shola which was released by MARC in 1998, is still widely produced by small-scale farmers and is a high yielder (under farmers condition 30 t.ha $^{-1}$ ) (Benti and Gemechu 2014) and (43 t.ha-1 in research plots) (Nasir et al. 2017; Tujuba and Ayana 2020). Basil genotype B04 is also a high yielder (herbage and essential oil yields) in the Wondo Genet area (Bhutia et al. 2018).

The experiment was laid down in Randomized Complete Block Design (RCBD) with the factorial arrangement in three replications, each with ten treatments (including sole plots of basil and tomato). The experiment consisted of four population densities of basil (100\%, 75\%, 50\%, 25\%) and two-row arrangements of intercropping tomato $(\mathrm{T})$ : basil (B) (1T:1B and 1T:2B), as well as sole plots of tomato and basil, making the total number of treatments ten. A uniform population of 33,333 plants ha-1 with $100 \mathrm{~cm}$ by $30 \mathrm{~cm}$ inters and intra-row spacing, respectively, was maintained for tomatoes in both cropping systems (for sole and intercropped plots). A population of 66,666 plants. ha- ${ }^{-1}$ with $50 \mathrm{~cm}$ by $30 \mathrm{~cm}$ inters and intra row spacing, respectively, was considered as an optimum density for a sole crop of basil. Besides, four different intercrop proportions of basil: 25\% (16666 plants.ha-1 $), 50 \%$ (33333 plants.ha-1), $75 \%$ (50000 plants.ha-1) and 100\% (66666 plants.ha-1) were also maintained in the experiment.

\section{Data collection and analysis}

Plant height, Number of branches per plant, Fresh leaf weight per plant (g), Dry leaf weight per plant (g), were recorded from five randomly taken plants from the net plots. Besides, days to $50 \%$ flowering and days to maturity were recorded. Dry leaf yield (kg/ha) and Fresh 
herbal weight $(\mathrm{kg} / \mathrm{ha})$ weight per hectare was calculated based on dry leaf weight and Fresh herbal weight per plant and converted to the hectare and the average value was computed. Essential oil content was determined by hydro-distillation method, according to the procedure described by (Bisrat et al. 2001) and essential oil yield per hectare was calculated by (Bisrat et al. 2001; Ghaffari et al. 2019) the formula as suggested by (Kasim et al. 2014).

For each measured response variable, analysis of variance (ANOVA) was carried out using Statistical Analysis System (SAS) software version 9.4 (Lakens and Caldwell 2021). Means of treatments showing significant effects were further separated by the least significant difference (LSD) test at 5\% probability level.

\section{RESULTS AND DISCUSSION \\ Response of basil to intercropping \\ Plant height.}

Sweet Basil Population density significantly $(p<0.05)$ influenced plant height, where the tallest plant $(37.93 \mathrm{~cm})$ was observed $100 \%$ basil population density, while the shortest $(31.66 \mathrm{~cm})$ was for $25 \%$ basil (Table 1$)$. The basil population density decreases from $100 \%$ to $25 \%$ plant height also decreases. It was observed from $37.93 \mathrm{~cm}$ to $31.66 \mathrm{~cm}$ the increase in plant height with increasing plant population could be due to increased competition for light. The present study was in line with the work of Alemu et al. (2018) who reported that as basil population density increases, the competition for sunlight and nutrient increased and, thus, stems length increased. Pereira et al. (2015) also reported that increased density increases the stem length of the plant due to increased competition between the plants for absorbing light to cause growth in their height. This result also showed that intercropping as compared to sole planting did not show significant $(p>0.05)$ variation for basil plant height. This could be due to less competition for light between basil and tomato under intercropping. In line with the present result, Souza et al. (2020) also reported that basil is a poor resource (water, nutrient, space, and light) competitor when grown together with tomatoes in the open field.

\section{Number of primary branches per plant}

Results of the analysis of variance revealed that row arrangement had a significant $(p<0.05)$ effect on the number of primary branches per plant. The highest number of primary branches (9.52) was recorded for the $1 \mathrm{~T}: 1 \mathrm{~B}$ row arrangement while the minimum value (8.03) was recorded $1 \mathrm{~T}: 2 \mathrm{~B}$ row arrangement of tomato to basil (Table 1). This might be due to closer inter-row spacing which could have more favored plant competition to nutrition, air. and other growth thereby reduced the vegetative growth of plants. decrease of plant density in a unit area may cause increased light absorption by plants and provide more space for plant development, Therefore, 1T:1B row arrangement has enough space for light absorption, as a result, more branches grow when compare with 1T:2B row arrangement. Similar results have also been reported by Fallah et al. (2018) who observed more branches at wider spacing because of enough space among plants to produce more branches.

\section{Fresh herbal yield per plant}

The analysis of variance showed population density had a significant $(p<0.05)$ effect on fresh herbal yield per plant. The maximum fresh herbal yield per plant $(30.76 \mathrm{~g})$ was recorded at $50 \%$ basil population density (Table 1 ). This might be because yields per plant decrease gradually as plant population per unit area increased. However, the yield per unit area increased due to the efficient utilization of growth factors. Maximum yield per unit area can be obtained when individual plants are subjected to severe competition (Lamlom and Ahmed 2021). Sadeghi et al. (2009) reported that basil is sensitive to plant density and lower densities do not produce sufficient fresh herbal yield per unit area. This result showed that intercropping as compared to sole planting did not affect fresh herbal per plants of basil. This indicated also that the basil plant can be tolerating tomato plants without adverse effects on individual fresh herbal yield under intercropped conditions. Similar results were reported by Rao (2002) indicating that intercropping of corn mint did not affect biomass yield of rose-scented geranium.

Table 1. Means for plant height, number of primary branches, fresh herbal and stem weight per plant of basil as affected by row arrangement, population density, and cropping system intercropped with tomato at Wondo Genet during 2017/2018 cropping system

\begin{tabular}{|c|c|c|c|c|}
\hline Treatments & $\mathrm{PH}(\mathrm{cm})$ & NPB & FHPP $(g)$ & FSPP $(g)$ \\
\hline \multicolumn{5}{|c|}{ Row arrangements } \\
\hline $1 \mathrm{~T}: 1 \mathrm{~B}$ & 34.56 & $9.52^{a}$ & 27.68 & 26.46 \\
\hline $1 \mathrm{~T}: 2 \mathrm{~B}$ & 35.42 & $8.03^{b}$ & 27.30 & 26.93 \\
\hline $\mathrm{LSD}_{0.05}$ & ns & 1.18 & ns & ns \\
\hline \multicolumn{5}{|c|}{ Population densities } \\
\hline $100 \%$ & $37.93^{a}$ & 9.28 & $27.73^{b}$ & $25.89^{b}$ \\
\hline $75 \%$ & $36.25 \mathrm{~b}$ & 8.93 & $26.64^{b}$ & $25.13^{b}$ \\
\hline $50 \%$ & $34.13^{c}$ & 8.76 & $30.76^{a}$ & $33.05^{a}$ \\
\hline $25 \%$ & $31.66^{d}$ & 8.13 & $24.84^{b}$ & $22.71^{b}$ \\
\hline $\mathrm{LSD}_{0.05}$ & 1.40 & ns & 3.83 & 5.02 \\
\hline CV (\%) & 3.24 & 15.39 & 11.26 & 15.2 \\
\hline \multicolumn{5}{|c|}{ Cropping systems } \\
\hline Sole & 34.41 & $11.39^{a}$ & 27.14 & 22.29 \\
\hline Intercropped & 35.42 & $8.03^{b}$ & 27.30 & 26.93 \\
\hline $\mathrm{LSD}_{0.05}$ & ns & 1.96 & ns & Ns \\
\hline CV (\%) & 3.38 & 9.73 & 5.55 & 10.89 \\
\hline
\end{tabular}

Means followed by the same letter with the same column for a given treatment are not significantly different at a $5 \%$ level of probability. ns= not significant; $\mathrm{PH}=$ plant height; $\mathrm{NPB}=$ number of primary branches per plant; FHPP=fresh herbal yield per plant; $F S P P=$ fresh stem weight per plant; $\mathrm{LSD}=$ least significant difference, $\mathrm{CV}=$ coefficient of variation, $1 \mathrm{~T}: 1 \mathrm{~B}=$ one tomato row alternating with one basil row, $1 \mathrm{~T}: 2 \mathrm{~B}=$ one tomato row alternating with two basil rows.

\section{Fresh stem weight per plant}

The population density was significantly $(p<0.05)$ affected, but row arrangement and cropping system did not significantly $(p>0.05)$ influence fresh stem weight per plant of basil. The maximum fresh stem weight per plant (33.05g) was recorded for $50 \%$ basil population density, while the least value $(24.84 \mathrm{~g})$ was recorded for $25 \%$ basil population density, which was statistically similar to the value obtained from $75 \%$ and $100 \%$ basil population density (26.64g and $27.73 \mathrm{~g}$, respectively) (Table 1 ). 
A decrease in the weight of individual plants at higher plant density might be due to a reduction in the growth and development of the plants. The present result was in agreement with the finding of Faridvand et al. (2021), who reported that basil benefited from the reduction of its companions and, with more access to light, it accumulated more chlorophyll and produced more aboveground biomass. Nigussie et al. (2017) reported that the highest and lowest stem fresh weights were observed at $80 \%$ and $20 \%$ population density of rosemary intercropped with onion.

\section{Herbal fresh weight per hectare}

Herbage fresh weight of basil was significantly $(P<0.05)$ influenced by the interaction of row arrangement and basil population density. The maximum fresh herbal yield $\left(2116.8 \mathrm{~kg} \mathrm{ha}^{-1}\right)$ was obtained from the 1T:2B row arrangement of tomato to basil combined with $100 \%$ basil population density, while the lowest value was obtained from the interaction of 1T:2B row arrangement with $25 \%$ basil population density (Figure 1). The increase in herbal fresh weight 1T:2B row arrangement and 100\% basil population density could be due to optimum radiation, nutrient, and water supply which allow basil to bear a large number of leaves and inflorescence thereby increasing herbage yield (Oroka 2011; Rostaei et al. 2018). A similar finding was reported by Carvalho et al. (2017), indicating that the herbal yield of basil was recorded when intercropped with tomato plants. Nthabiseng et al. (2015) also reported that the biomass and grain yield of cowpea increased at a high density of cowpea on a millet-cowpea intercropping system.

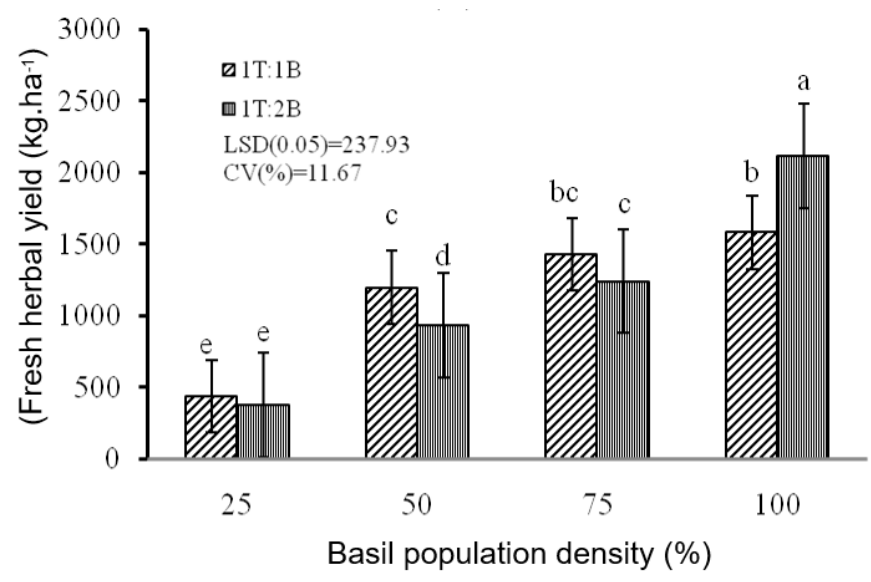

Figure 1. The interaction effect of population density and row arrangement of basil in tomato basil intercropping on basil fresh herbal yield. Bars capped with the same letter (s) are not significantly different at $p \leq 0.05$

\section{Dry herbal yield per hectare}

It was observed that both the main factors and their interaction had a significant $(p<0.05)$ influence on dry herbal yield per hectare. The maximum dry herbal yield (341.49 kg.ha-1) was recorded for 1T:2B row arrangement with $100 \%$ basil density, whereas the lowest value was obtained from 1T:1B row arrangement with $25 \%$ basil population density (Figure 2). Dry herbal yield followed the same trend as fresh herbal yield. In line with this Barickman et al. (2021) reported that the maximum herbal yield of rosemary was obtained with $80 \%$ rosemary intercropped with onion. Oroka (2011) has also reported that the maximum density of intercrops resulted in the maximum forage dry matter yield of rice intercropped with cowpea. Herbage dry yield of basil, on the other hand, was not significantly $(p>0.05)$ affected by the cropping system. In line with this result, Abera and Gerkabo (2021) reported that the herbal yield of basil was not significantly varied with sole planting and 1:1 row arrangement in maize-basil intercropping. This might be due to the presence of less competition between basil and tomato when intercropped. In agreement with the present study, Formisano et al. (2021) reported that the highest herbal yield in of basil was recorded for both mono-cropping and intercropping with tomato plants. Fresh herb yield was highest for the sole Japanese mint plot, which was statistically on par with intercropping Japanese mint plus one row of onion (Rivest et al. 2009; Roshetko et al. 2013; Daneshnia et al. 2016).

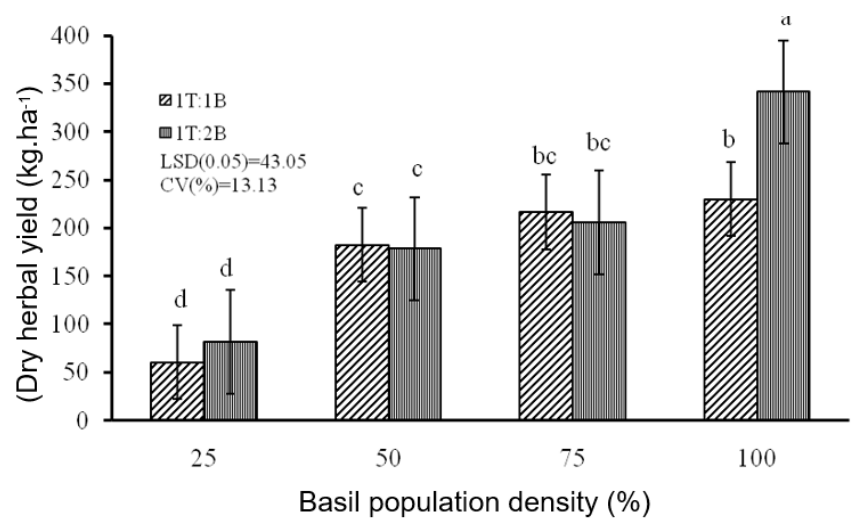

Figure 2. The interaction effect of population density and row arrangement of basil on herbal dry yield basil yield. Bars capped with the same letter (s) are not significantly different at $p \leq 0.05$

\section{Essential oil content}

Essential oil content was not significantly $(p>0.05)$ affected by the interaction of main factors, but row arrangement and population density had a significant $(p<0.05)$ effect. A similar result has been reported by Mirjalili and Poorazizi (2014) indicating that plant density significantly affected the essential oil content of basil. Higher essential oil content (1.17\%) was obtained from 1T:1B row arrangement as compared with 1T:2B row arrangement $(0.95 \%)$ (Table 2). This could be since at wider row spacing, the competition between the plants reduces, and hence, each plant has more space and produces more leaves. In addition, the essential oil content of plants under high light was more than that of plants grown with low light as biosynthesis of essential oil is highly dependent on light conditions (Gavrić et al. 2021). In line with this, Mirjalili and Poorazizi (2014) reported that two-row cultivation of basil, with low density, resulted in a higher yield of essential oil.

The highest essential oil content (1.13\%) was obtained from $100 \%$, followed by $75 \%(1.12 \%)$ and $50 \%$ basil population density (1.1\%), while $25 \%$ basil population density had the least value $(0.88 \%)$ (Table 2$)$. This result indicates that as population density increases the essential oil content of basil also increases. In line 
with this, it has been reported that plant population densities affected plant growth by subsequently influencing the absorption of nutrients and exposure of plants to the light, which has a direct effect on photosynthesis and the production of essential oil (Akbari et al. 2018; Alemu et al. 2018; Lin et al. 2021). Singh (2015) also reported that as basil population density increases, the essential oil content also increased.

The cropping system had a significant $(p<0.05)$ influence on the essential oil content of basil, which was higher in solely planted basil (1.26\%) when compared with basil intercropped with tomato $(0.96 \%)$ (Table 2). This might be due to the case that solely planted basil didn't suffer from competition with tomato plants and, thus had higher production of essential oil than did the intercropped plot. However, intercropping basil with tomato affected the amount of sunlight that passes through the canopies, which could influence the photosynthetic rates of the leaves within the canopy. The higher essential oil content of spearmint was obtained from sole planting as compared to the intercropped spearmint with maize (Nigussie et al. 2017; Kebede and Bogale 2019).

Table 2. Fresh herbal weight, fresh stem weight, dry herbal weight, and essential oil content of basil as affected by row arrangement, population density, and cropping system under intercropping with tomato at Wondo genet during 2017/2018 season

\begin{tabular}{|c|c|c|c|c|}
\hline Treatments & $\begin{array}{l}\text { FHW } \\
\left(\mathrm{kg} \mathrm{ha}^{-1}\right)\end{array}$ & $\begin{array}{l}\text { FSW } \\
\left(\mathrm{kg} \mathrm{ha}^{-1}\right)\end{array}$ & $\begin{array}{l}\text { DHW } \\
\left(\mathrm{kg} \mathrm{ha}^{-1}\right)\end{array}$ & $\begin{array}{l}\text { EOC } \\
(\%)\end{array}$ \\
\hline \multicolumn{5}{|c|}{ Row arrangements } \\
\hline $1 \mathrm{~T}: 1 \mathrm{~B}$ & 1160.59 & 1067.68 & $172.53^{b}$ & $1.17^{\mathrm{a}}$ \\
\hline $1 \mathrm{~T}: 2 \mathrm{~B}$ & 1167.14 & 1156.89 & $201.90^{\mathrm{a}}$ & $0.95^{b}$ \\
\hline $\mathrm{LSD}_{0.05}$ & ns & ns & 21.53 & 0.13 \\
\hline \multicolumn{5}{|c|}{ Population densities } \\
\hline $100 \%$ & $1848.54^{a}$ & $1726.00^{a}$ & $285.77^{a}$ & $1.14^{\mathrm{a}}$ \\
\hline $75 \%$ & $1332.07^{b}$ & $1256.40^{b}$ & $211.31^{b}$ & $1.12^{\mathrm{a}}$ \\
\hline $50 \%$ & $1064.93^{c}$ & $1101.90^{b}$ & $180.63^{c}$ & $1.11^{\mathrm{a}}$ \\
\hline $25 \%$ & $409.94^{d}$ & $364.90^{c}$ & $71.14^{d}$ & $0.88^{b}$ \\
\hline $\mathrm{LSD}_{0.05}$ & 168.24 & 225.52 & 30.44 & 0.18 \\
\hline CV (\%) & 11.67 & 16.37 & 13.13 & 13.63 \\
\hline \multicolumn{5}{|c|}{ Cropping systems } \\
\hline Sole & 1607.60 & 1573.56 & 228.88 & $1.26^{a}$ \\
\hline Intercropped & 1581.90 & 1346.17 & 226.89 & $0.96^{b}$ \\
\hline LSD $_{0.05}$ & ns & ns & ns & 0.22 \\
\hline CV (\%) & 9.32 & 9.48 & 5.99 & 9.80 \\
\hline
\end{tabular}

Means followed by the same letter within a column for a given treatment are not significantly different at a $5 \%$ level of probability. ns $=$ not significant; $\mathrm{FHW}=$ fresh herbal weight, $\mathrm{FSW}=$ fresh stem weight, $\mathrm{DHY}=$ dry herbal yield $(\mathrm{kg} / \mathrm{ha}) ; E O C=e s s e n t i a l$ oil content; EOY=essential oil yield; $L S D=$ Least significant difference, $C V=$ Coefficient of variation

\section{Essential oil yield}

The result of this study revealed that the interaction of row arrangement and population density of basil significantly $(p<0.05)$ influenced the essential oil yield of basil. A similar result has been reported by Atghaei et al. (2020) where different intercropping patterns significantly affected the essential oil content of Japanese mint. The highest essential oil yield (22.86 $\mathrm{kg} \cdot \mathrm{ha}^{-1}$ ) was obtained from the 1T:2B row arrangement combined with $100 \%$ population density of basil, while the lowest value was obtained from the $1 \mathrm{~T}: 2 \mathrm{~B}$ row arrangement with $25 \%$ population density $\left(4.26 \mathrm{~kg} \cdot \mathrm{ha}^{-1}\right)$ of basil (Figure 3). The reduction in essential oil yield of basil with decreasing basil population density might be probably due to decreased herbal biomass yield. The higher essential oil yield for higher plant density for sweet basil (Arsovski et al. 2018; Barickman et al. 2021; Qi et al. 2021). Ebenezer et al. (2019) also reported higher EO yield under narrow $(30 \mathrm{~cm})$ inter-row spacing for Japanese mint. The highest essential oil yield was obtained from solely planted basil $\left(21.82 \mathrm{~kg} \mathrm{ha}^{-1}\right)$ as compared with the intercropped basil $\left(15.36 \mathrm{~kg}^{-\mathrm{ha}^{-1}}\right)$. This result was in line with the finding of (Pereira et al. 2015; Salaheen and Biswas 2019) indicating increased basil essential oil yield during sole cropping in comparison with a mixed cropping system. Similar results have been reported by Bitew et al. (2021) for rosemary-onion intercropping, where rosemary essential oil yield was higher in the sole as compared to the intercropped plot.

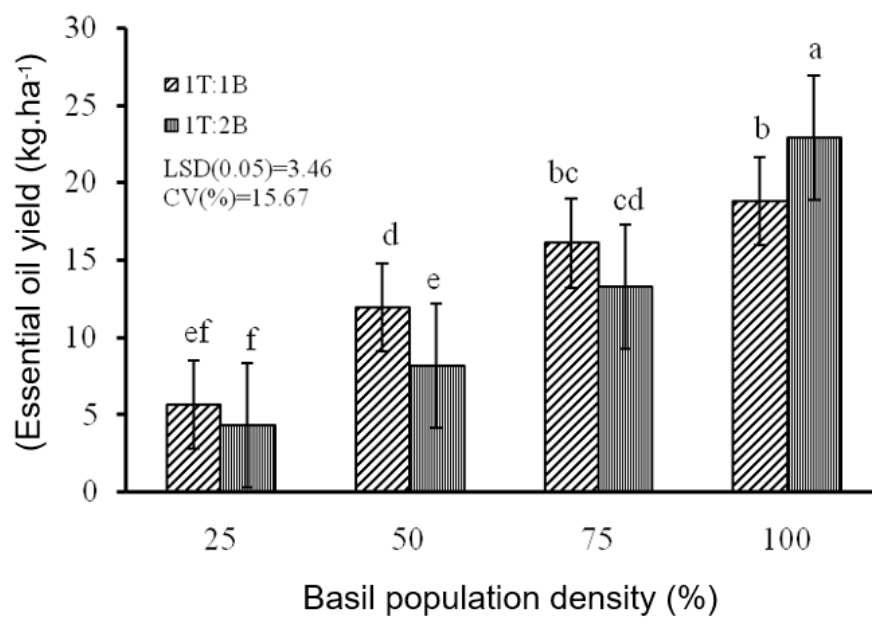

Figure 3. The interaction of population density and row arrangement of basil intercropped with tomato on basil essential oil yield. Bars capped with the same letter (s) are not significantly different at $p \leq 0.05$

\section{CONCLUSIONS}

The present experiment was conducted at Wondo Genet Agricultural Research Center, southern Ethiopia under irrigated conditions in 2017/2018 to determine the optimum planting density and row arrangements of basil for intercropping with tomato. Basil population density and row arrangement showed a highly significant variation in different growth and yield parameters of basil. Fresh and dry herbal yield per hectare and essential oil yield of basil were affected by the interaction of basil population density and row arrangement of tomato and 
basil. As a result, the maximum fresh and dry herbal yield per hectare and essential oil yield of basil $\left(2116.8 \mathrm{~kg} . \mathrm{ha}^{-1}\right.$, $341.49 \mathrm{~kg} \cdot \mathrm{ha}^{-1}$, and $22.86 \mathrm{~kg} \cdot \mathrm{ha}^{-1}$ respectively) were obtained from $100 \%$ basil population density intercropped at 1T:2B tomato to basil row arrangement. Therefore, basil with a density of 33,333 plants.ha ${ }^{-1}$ by one tomato row alternating one basil row arrangement could be recommended for intercropping with tomato in the target area, based on its better compatibility and productivity.

\section{ACKNOWLEDGEMENTS}

I would like to pay my sincere gratitude to Wondo Genet Agricultural Research Center (WGARC) for facilitating my study, Ethiopian Institute of Agricultural Research (EIAR) for the financial support. I am especially very thankful to Mr. Muluken Philipos, center director, Mr. Wondu Bekele center crop research representative, Ms. Nibret Tadesse, Agronomy case team for giving me experimental plots and for their kind facilitation. My special thanks go to Ms. Alemitu Taka for her support during field data collections and the WGARC laboratory team for laboratory tests. My thanks extend to all my friends for their priceless support.

\section{REFERENCES}

Abera G, Gerkabo H. 2021. Effects of green manure legumes and their termination time on yield of maize and soil chemical properties. Arch Agron Soil Sci. 67(3):397-409.

https://doi.org/10.1080/03650340.2020.1733536.

Adeniyi OR, Omotunde CT. 2001. Effect of Planting Pattern on Growth and Yield of Tomato-Cowpea Intercrops. J Veg Crop Prod. 7(2):75-81. https://doi.org/10.1300/J068v07n02_08.

Akbari GA, Soltani E, Binesh S, Amini F. 2018. Cold tolerance, productivity and phytochemical diversity in sweet basil (Ocimum basilicum L.) accessions. Ind Crops Prod. 124(August):677-684. https://doi.org/10.1016/j.indcrop.2018.08.048.

Alemu A, Garedew W, Gebre A. 2018. Essential oil yield and yield components of basil (Ocimum basilicum L.) as affected by genotype and intrarow spacing at Jimma, SW Ethiopia. Acta Agrobot. 71(3):1-9. https://doi.org/10.5586/aa.1743.

Arsovski AA, Zemke JE, Haagen BD, Kim SH, Nemhauser JL. 2018. Phytochrome B regulates resource allocation in Brassica rapa. J Exp Bot. 69(11):2837-2846. https://doi.org/10.1093/jxb/ery080.

Atghaei M, Sefidkon F, Darini A, Sadeghzadeh Hemayati S, Abdossi V. 2020. Essential Oil Content and Composition of the Spathe in Some Date Palm (Phoenix dactylifera L.) Varieties in Iran. J Essent OilBearing Plants. 23(2):292-300. https://doi.org/10.1080/0972060X.2020.1743768.

Barickman TC, Brazel S, Sehgal A, Walne CH, Gao W, Reddy KR. 2021. Individual and interactive temporal implications of uv-b radiation and elevated co2 on the morphology of basil (Ocimum basilicum I.).
Horticulturae.

$7(11)$

https://doi.org/10.3390/horticulturae7110474.

Benti G, Gemechu F. 2014. Parasitic contamination on vegetables irrigated with Awash River in selected farms, Eastern Showa, Ethiopia. J Parasitol Vector Biol https://doi.org/10.5897/JPVB2014.0150. 5(7):103-109.

Bhutia KG, Sood M, Bhutia PL. 2018. The effect of different planting time and harvesting schedules on growth and yield of Acorus calamus. Int J Chem Stud. 6(6):1608-1614.

Bisrat D, Abate S, Kebede W. 2001. Technical Manual 23 Manual for Plant Products Analysis. Addis Ababa: EJAR.

Bitew Y, Derebe B, Worku A, Chakelie G. 2021. Response of maize and common bean to spatial and temporal differentiation in maize-common bean intercropping. PLoS One. 16(10 October):1-17. http://dx.doi.org/10.1371/journal.pone.0257203.

Carvalho MG, Bortolotto OC, Ventura MU. 2017. Aromatic plants affect the selection of host tomato plants by Bemisia tabaci biotype B. Entomol Exp Appl.

https://doi.org/10.1111/eea.12534.

162(1):86-92.

Crusciol CAC, Nascente AS, Mateus GP, Pariz CM, Martins PO, Borghi E. 2014. Intercropping soybean and palisade grass for enhanced land use efficiency and revenue in a no till system. Eur J Agron. 58:5362. http://dx.doi.org/10.1016/j.eja.2014.05.001.

Daneshnia F, Amini A, Chaichi MR. 2016. Berseem clover quality and basil essential oil yield in intercropping system under limited irrigation treatments with surfactant. Agric Water Manag. 164:331-339.

https://doi.org/10.1016/j.agwat.2015.10.036.

Ebenezer KS, Manivannan R, Punniyamoorthy A. 2019. Plant Secondary Metabolites of Antiviral Properties a Rich Medicinal Source for Drug Discovery: A Mini Review. J Drug Deliv Ther. 9(5):161-167.

Ebert AW. 2014. Potential of underutilized traditional vegetables and legume crops to contribute to food and nutritional security, income and more sustainable production systems. Sustainability. 6(1):319-335. https://doi.org/10.3390/su6010319.

Fallah S, Rostaei M, Lorigooini Z, Abbasi Surki A. 2018. Chemical compositions of essential oil and antioxidant activity of dragonhead (Dracocephalum moldavica) in sole crop and dragonhead- soybean (Glycine max) intercropping system under organic manure and chemical fertilizers. Ind Crops Prod. 115(February):158-165. https://doi.org/10.1016/j.indcrop.2018.02.003.

Faridvand S, Rezaei-Chiyaneh E, Battaglia ML, Gitari HI, Raza MA, Siddique KHM. 2021. Application of bio and chemical fertilizers improves yield, and essential oil quantity and quality of Moldavian balm (Dracocephalum moldavica L.) intercropped with 
mung bean (Vigna radiata L.). Food Energy Secur.(July). https://doi.org/10.1002/fes3.319.

Formisano L, Ciriello M, El-Nakhel C, Kyriacou MC, Rouphael Y. 2021. Successive harvests modulate the productive and physiological behavior of three genovese pesto basil cultivars. Agronomy. 11(3):110. https://doi.org/10.3390/agronomy11030560.

Gavrić T, Jurković J, Gadžo D, Čengić L, Sijahović E, Bašić F. 2021. Fertilizer effect on some basil bioactive compounds and yield. Cienc e Agrotecnologia. 45. https://doi.org/10.1590/1413-7054202145003121.

Gebru H. 2015. A Review on the Comparative Advantage of Intercropping Systems. J Biol Agric Healthc. 5(9):28-38.

Ghaffari Z, Rahimmalek M, Sabzalian MR. 2019. Industrial Crops \& Products Variation in the primary and secondary metabolites derived from the isoprenoid pathway in the Perovskia species in response to different wavelengths generated by light emitting diodes (LEDs). Ind Crop Prod. 140(August):111592.

https://doi.org/10.1016/j.indcrop.2019.111592.

Gomes M, Silva DA, Pedro V, Silva DA. 2021. Biomass production and essential oil content and composition in basil hydroponic systems using treated domestic effluents Producción de biomasa, contenido y composición del aceite esencial de albahaca en sistemas hidropónicos utilizando efluentes domésti. Rev Colomb Ciencias Hortic. 15(2):0-3.

Hage-Ahmed K, Krammer J, Steinkellner S. 2013. The intercropping partner affects arbuscular mycorrhizal fungi and Fusarium oxysporum f. sp. lycopersici interactions in tomato. Mycorrhiza. 23(7):543-550. https://doi.org/10.1007/s00572-013-0495-x.

Kasim NN, Ismail NASS, Masdar ND, Hamid FA, Nawawi WI. 2014. Extraction and Potential of Cinnamon Essential Oil towards Repellency and Insecticidal Activity. Int J Sci Res Publ. 4(7):2250-3153.

Kebede BL, Bogale T. 2019. Intercropping of Sweet Basil (Ocimum Basilicum L.) with Maize (Zea Mays L.) as Supplementary Income Generation at Wondo Genet Agricultural Research Center, South Ethiopia. Int J Res Stud Agric Sci. 5(9). https://doi.org/10.20431/2454-6224.0509005.

Lakens D, Caldwell AR. 2021. Simulation-Based Power Analysis for Factorial Analysis of Variance Designs. Adv Methods Pract Psychol Sci. 4(1). https://doi.org/10.1177/2515245920951503.

Lamlom M, Ahmed A. 2021. Effect of intercropping systems of sesame with tomatoes under different intercropping dates of sesame on productivity of both crops. Egypt J Agric Res. 0(0):0-0. https://doi.org/10.21608/ejar.2021.50952.1044.

Lin K, Huang M, Hsu M. 2021. Scientia Horticulturae Morphological and physiological response in green and purple basil plants (Ocimum basilicum ) under different proportions of red, green, and blue LED lightings. Sci Hortic (Amsterdam). 275(July 2019):109677.

https://doi.org/10.1016/j.scienta.2020.109677.

Lulie B. 2017. Intercropping Practice as an Alternative Pathway for Sustainable Agriculture : A review Belstie Lulie Intercropping Practice as an Alternative Pathway for Sustainable Agriculture : A review. Acad Res J Agric Sci Res. 5(6):440-452. https://doi.org/10.14662/ARJASR2017.057.

Machiani MA, Rezaei-Chiyaneh E, Javanmard A, Maggi F, Morshedloo MR. 2019. Evaluation of common bean (Phaseolus vulgaris L.) seed yield and qualiquantitative production of the essential oils from fennel (Foeniculum vulgare Mill.) and dragonhead (Dracocephalum moldavica L.) in intercropping system under humic acid application. J Clean Prod. 235:112-122.

https://doi.org/10.1016/j.jclepro.2019.06.241.

Mirjalili SA, Poorazizi E. 2014. Effects of density and cultivation method on ratio and yield of essential oil in basil (Ocimum basilicum L .). Int J Agron Agric Res. 4(4):117-123.

Mishra B, Bose SK, Sangwan NS. 2020. Comparative investigation of therapeutic plant Withania somnifera for yield, productivity , withanolide content, and expression of pathway genes during contrasting seasons. Ind Crop Prod. 154(September 2019):112508.

https://doi.org/10.1016/j.indcrop.2020.112508.

Nasir S, Regasa T, Yirgu M. 2017. Influenced of Clove Weight and Depth of Planting on Yield and Yield Components of Garlic (Allium sativum L.) at Madawalabu University Experimental Site, Bale Zone, South Eastern Ethiopia. J Agric Environ Sci. 17(3):227-231.

https://doi.org/10.5829/idosi.aejaes.2017.227.231.

Nigussie A, Lulie B, Chala M. 2017. Intercropping of Onion with Rosemary as Supplementary Income Generation at Wondo Genet Sidama zone, Southern Ethiopia. Acad Res J Agric Sci Res. 5(2):107-115.

Nthabiseng T, Irvine KM, Moshibudi PM. 2015. Response of a maize or dry bean intercrop to maize density and dry bean arrangement under rainfed conditions. Int J Agron Agric Res. 6(6):18-29.

Oroka FO. 2011. Water hyacinth-based vermicompost on yield, yield components, and yield advantage of cassava+groundnut intercropping system. J Trop Agric. 50:49-52.

Pereira ALC, Taques TC, Valim JOS, Madureira AP, Campos WG. 2015. The management of bee communities by intercropping with flowering basil (Ocimum basilicum) enhances pollination and yield of bell pepper (Capsicum annuum). J Insect Conserv. 19(3):479-486. https://doi.org/10.1007/s10841-0159768-3.

Qi D, Wu Z, Yang C, Xie G, Li Z, Yang X, Li D. 2021. Can intercropping with native trees enhance structural stability in young rubber (Hevea brasiliensis) 
agroforestry system? Eur J Agron. 130(July 2020):126353.

https://doi.org/10.1016/j.eja.2021.126353.

Rao BRR. 2002. Biomass yield, essential oil yield and essential oil composition of rose-scented geranium (Pelargonium species) as influenced by row spacings and intercropping with cornmint (Mentha arvensis L.f. piperascens Malinv. ex Holmes). Ind Crops Prod. 16(2):133-144. https://doi.org/10.1016/S09266690(02)00038-9.

Rivest D, Cogliastro A, Olivier A. 2009. Tree-based intercropping systems increase growth and nutrient status of hybrid poplar: A case study from two Northeastern American experiments. J Environ Manage.

http://dx.doi.org/10.1016/j.jenvman.2009.09.013.

Roshetko JM, Rohadi D, Perdana A, Sabastian G, Nuryartono N, Pramono AA, Widyani N, Manalu P, Fauzi MA, Sumardamto P, et al. 2013. Teak agroforestry systems for livelihood enhancement, industrial timber production, and environmental rehabilitation. For Trees Livelihoods. 22(4):241-256. http://dx.doi.org/10.1080/14728028.2013.855150.

Rostaei M, Fallah S, Lorigooini Z, Abbasi Surki A. 2018. The effect of organic manure and chemical fertilizer on essential oil, chemical compositions and antioxidant activity of dill (Anethum graveolens) in sole and intercropped with soybean (Glycine max). J Clean Prod. 199:18-26. https://doi.org/10.1016/j.jclepro.2018.07.141.

Sadeghi S, Rahnavard A, Ashrafi ZY. 2009. The effect of plant density and sowing date on yield of Basil
(Ocimum basilicum L.) in Iran. J Agric Technol. 5(2):413-422.

Salaheen S, Biswas D. 2019. Organic farming practices: Integrated culture versus monoculture. Elsevier Inc. http://dx.doi.org/10.1016/B978-0-12-812060-6.00002-7.

Sattler J, Bartelheimer M. 2018. Root responses to legume plants integrate information on nitrogen availability and neighbour identity. Basic Appl Ecol. 27(2017):51-60. http://dx.doi.org/10.1016/j.baae.2018.01.001.

Singh S. 2015. Planting row arrangement and nutrient management in geranium (Pelargonium graveolens) - garlic (Allium sativum) intercropping. Indian J Agric Res. https://doi.org/10.18805/ijare.v49i5.5802.

Souza MAADE, Braga RP, Santos AMDOS. 2020. Productive, metabolic and anatomical parameters of menthol mint are infl uenced by light intensity. An Acad Bras Cienc. 92:1-15. https://doi.org/10.1590/0001-3765202020180321.

Tujuba M, Ayana NG. 2020. Evaluation of Released Tomato (Lycopersicon Esculentum Mill .) Varieties for Fruit Yield and Quality Parameters in Western Ethiopia. Agric Biol Sci J Vol. 6(2):100-113.

Yaldiz G, Camlica M. 2021. Agro-morphological and phenotypic variability of sweet basil genotypes for breeding purposes. Crop Sci. 61(1):621-642. https://doi.org/10.1002/csc2.20391.

Yildirim E, EkIncl M. 2017. Intercropping Systems in Sustainable Agriculture. Ziraat Fakültesi Derg. 12(1):100-110. 